\title{
Economics and marketing of dry fish production in Thoothukudi District, Tamil Nadu, India
}

\author{
M. S. MADAN ${ }^{1}$, KALIDOSS RADHAKRISHNAN $^{1 *}$, L. RANJITH ${ }^{1}$, R. NARAYANAKUMAR ${ }^{2}$, \\ N. ASWATHY ${ }^{3}$ AND K. P. KANTHAN ${ }^{1}$ \\ ${ }^{1}$ Tuticorin Research Centre of ICAR-Central Marine Fisheries Research Institute, Thoothukudi - 628001 \\ Tamil Nadu, India \\ ${ }^{2}$ Madras Research Centre of ICAR-Central Marine Fisheries Research Institute, Chennai - 628001 \\ Tamil Nadu, India \\ ${ }^{3}$ ICAR-Central Marine Fisheries Research Institute, Kochi - 682 018, Kerala, India \\ e-mail: theradhakrishnan@outlook.com
}

\begin{abstract}
The present study attempted to evaluate the economics and marketing of dry fish production in Thoothukudi District of Tamil Nadu, India. The information on various aspects of the dry fish enterprise was collected through random sampling of 29 dry fish producers in a pre-structured interview schedule. The results indicated that $50 \%$ of the total dry fish produced (in terms of quantity) was contributed by sardines and anchovies. However, seer fishes fetched a premium market price of $₹ 550 \mathrm{~kg}^{-1}$ followed by carangids (₹ $125 \mathrm{~kg}^{-1}$ ) and belonids (₹ $115 \mathrm{~kg}^{-1}$ ). Dry fish production was found to be a profitable business with an internal rate of returns (IRR) of $75 \%$ and simple rate of returns (SRR) of $43.48 \%$ respectively with a net profit margin of ₹2258.83 week ${ }^{-1}$. The study also suggests that the dry fishes reached the consumers by way of three marketing channel viz., channel 1 (producer to consumer) channel 2 (producer, middleman and consumer) and channel 3 (producer, wholesaler, middleman and consumer). Channel 1 was found the most efficient marketing channel over channel 2. The cost of raw materials, transportation, packaging and marketing margin were found to be the key factors that influences and decides the income of the dry fish producers and all the factors exhibited statistical significance at 0.05 level.
\end{abstract}

Keywords: Byproduct, Marketing channel, Production economics, South-east coast of India

\section{Introduction}

Nearly one-third of the food produced for the human consumption (1.3 billion $\mathrm{t}$ year $\left.{ }^{-1}\right)$ was wasted from the entire production to consumption system (FAO, 2011), the major losses being attributed to improper storage and untimely processing including drying the foodstuff (Kallon et al., 2017). India lacks adequate post-harvest infrastructure facilities to process and store dry fishes. There is a huge landing of undersised and low market value fishes as bycatch, which are mostly discarded at sea during peak fishing seasons. During lean fishing seasons, these fishes are brought to the fish landing centres by the fishermen, due to demand from the dry fish enterprise. Dry fishes can be transported to areas where these fishes have good market potential. Dry fish attracts greater demand during fishing ban period when availability of fresh fish in the market is low (Das et al., 2013). Dry fish has higher concentration of protein (in terms of weight) as compared to the wet weight of fish and therefore is a cheap source of animal protein. Hence, dry fish production provides employment opportunity especially to women and generate income to the fishers (Kallon et al., 2017), in addition to the contribution towards nutritional security of the poor. As per CMFRI (2010), females are more actively involved in curing/processing as well as marketing of dry fish.

Drying of fish was a well-known method of fish preservation prior to the introduction of canning and freezing (Balachandran, 2001). Dry fish preservation is an alternative dimension to reduce the physical post-harvest loss of bycatch and improve value addition (Payra et al., 2016). In India, dry fishes are widely sold at local markets and commercially important species are also exported to other countries (Immaculate et al., 2013). Dry fish being a low cost dietary protein food, with the growing importance of dry fish, studies on various aspects such as traditional method of dry fish production and their problems (Payra et al., 2016); different methods of dry fish production and their yield (Bharda et al., 2017) as well as nutritional and microbial quality of major sun-dried fishes (Kundu et al., 2016) have been undertaken. Though dry fish enterprise has a significant role in the improvement of livelihood 
of the fishers and nutritional security of the society, not much attention has been paid to document the different avenues on the dry fish products. Hence, the present study was attempted to address the economics of dry fish production, its financial feasibility and how the dry fish reached consumer.

\section{Materials and methods}

\section{Study area and duration}

This study was conducted in Thoothukudi District of Tamil Nadu, owing to the concentration of the dry fish producers in the region. Data was collected during September 2013 to February 2014 using a well-structured interview schedule, which was designed to acquire the relevant informations like drying process, species composition, price of the fish, investment, cost details and marketing channels. A random sampling of 29 dry fish producers from northern (Tharuvaikulam, Vembar and Vaipar) and southern (Veerapandianpattinam, Punnaikayal and Pazhayakayal) part of Thoothukudi was done for the survey.

\section{Investment analysis}

Capital is the most limiting of resources used in fisheries over a longer period and efficiency of its use is very important. Capital is classified into two broad categories namely investment and operating capital. Investment capital is long-term capital used to acquire capital goods while operating capital is used to cover the operating expenses (Engle, 2010).

For an investment analysis, the initial cost of investment, net cash revenues, salvage value of investment and interest rate are required. The initial cost of investment is the actual expenditure incurred for the equipment/ machinery or infrastructure. Net cash revenue is the amount received from the sale of dry fish and estimated for the period by subtracting the expenses from the cash receipt. Salvage value is the estimated resale value of an asset at the end of its useful life. The discount rate is the opportunity cost of capital investment. The investment analysis was worked out as per Radhakrishnan et al. (2018). The discounted cash flow methods were employed, which includes the net present value (NPV), simple rate of return (SRR), payback period (PBP) and benefit-cost ratio (BCR).

NPV is the difference between the present value of cash inflow and present value of cash outflow over a period. It was estimated with an assumption of a $14 \%$ interest rate. Mathematically, NPV was calculated as:

$$
\mathrm{NPV}=\frac{\mathrm{P}_{1}}{(1+\mathrm{i})^{1}}+\frac{\mathrm{P}_{2}}{(1+\mathrm{i})^{2}}+\cdots \frac{\mathrm{P}_{\mathrm{n}}}{(1+\mathrm{i})^{\mathrm{n}}}-\mathrm{C}+\text { Salvage value }
$$

where, $\mathrm{P}_{n}$ is net cash flow in year " $\mathrm{n}$ "; $\mathrm{i}$ is discount rate and $\mathrm{C}$ is initial cost of investment.

SRR is the annual net revenue from the sale of dry fish expressed as percentage of investment, calculated as:

$$
\mathrm{SRR}=\frac{\text { Average annual net revenue }}{\text { Cost of the investment }} \times 100
$$

The payback Period (PBP) is the number of years it would take for an investment to return its cost through annual net revenue and was calculated as:

$$
\mathrm{P}=\frac{\mathrm{I}}{\mathrm{E}}
$$

where, I is the amount of investment and $\mathrm{E}$ is the anticipated annual net revenue

Benefit-cost ratio (BCR) is the relationship between the present value of cash inflow and the present value of cash outflow and also known as profitability index. BCR was calculated using the formula:

$$
\mathrm{BCR}=\frac{\text { Discounted stream of benefit }}{\text { Discounted stream of cost }} \times 100
$$

\section{Cost and return analysis}

An economic analysis of dry fish production was performed to determine the net return. This analysis was based on the price received from the sale of dry fish (gross income), variable cost (input cost paid) and fixed cost. The salvage value was $10 \%$ of the initial investment cost, which was used for the calculation of the depreciation.

Total cost $=$ Total variable cost + Total fixed cost

Total variable cost is sum of all the variable cost such as the cost of fish, transport cost, cost of processing and salting, labour cost, packaging cost, handling charge and market levy. Total fixed cost is sum of all fixed costs such as repair and maintenance of the dry fish yard building and tanks, interest on investment and depreciation.

Depreciation $=$ Purchase price - Salvage value/Economic life

Gross income $=$ Total production $\mathrm{x}$ Actual sale value

Net income $=$ Gross income - Total cost

\section{Market efficiency and margin}

Marketing efficiency is the ratio of market output to market input and is the degree of marketing performance. Increasing ratio represents improved efficiency and decrease denotes reduced efficiency (Acharya and Agarwal, 2004).

Marketing efficiency $=\quad \frac{\text { Gross revenue }}{\text { Total marketing cost }}$ 
Net marketing margin is the relationship between the gross revenue and total variable cost of the fish.

$$
\text { Net marketing efficiency }=\frac{\text { Gross revenue }}{\text { Total variable cost }}
$$

Marketing margin is the difference between the price paid by the dry fish consumer and that received by the dry fish producers.

$$
\text { Market margin }=\frac{\text { Selling price }- \text { Cost of fish }}{\text { Selling price }} \times 100
$$

Carcass recovery of fish is the difference between the weight of the fish after drying and fresh fish weight which was computed using the formula:

$$
\text { Carcass recovery of fish }=\frac{\text { Weight of fish after drying }}{\text { Fresh fish weight }} \times 100
$$

\section{Regression analysis}

Multiple linear regression analysis was applied to assess the factors influencing the income of dry fish producers. The explanatory variables (cost of fish, transport charge, packaging cost, market rent, marketing margin, market distance, age, literacy and experience) were assumed to explain the income of dry fish producer. It was hypothesised that a change in the amount of inputs does not affect the income of the dry fish producer. In the multiple linear regression model, the dependent variable is described as a linear function of the independent variable, as in the following general form:

$$
\mathrm{Y}=\mathrm{a}+\mathrm{b}_{1} \mathrm{X}_{1}+\mathrm{b}_{2} \mathrm{X}_{2}+\cdots+\mathrm{b}_{\mathrm{n}} \mathrm{X}_{\mathrm{n}}+\varepsilon
$$

where, $\mathrm{Y}$ is income, $\mathrm{X}_{1}$ is cost of fish, $\mathrm{X}_{2}$ is transport cost, $\mathrm{X}_{3}$ is package cost, $\mathrm{X}_{4}$ is market levy, $\mathrm{X}_{5}$ is purchase quantity, $\mathrm{X}_{6}$ is labour wages, $\mathrm{X}_{7}$ is carcass recovery ratio and error term. This model permits computation of a regression coefficient and $b_{i}$ for each independent variable $\mathrm{X}_{\mathrm{i}}$.

\section{Results and discussion}

\section{Historical trend}

In the past half century, of the total fish production in India, 7.26\% fish was not consumed (Fig. 1). There was an increasing trend in export of dried fish, which was at a subsistence scale i.e., $7506 \mathrm{t}$ in 1995 increased to commercial scale (88997 t) during 2017 (Fig. 2).The pelagic fishes, 0.272 million $\mathrm{t}$ and 0.409 million $\mathrm{t}$ were used for feed and for other uses respectively in 2013 (Table 1). Oilsardine alone accounted $35 \%$ of the total pelagic fish landing, followed by ribbon fishes (11\%), carangids $(10 \%)$, other sardines $(7 \%)$, Bombayduck $(6 \%)$, anchovies $(5 \%)$, other clupeids $(4 \%)$ and other pelagic species (15\%) during 2012 (CMFRI, 2012-13).

\section{Production process}

In total about 499 nos. of dry fish producers are available all along the study areas and major drying yards are located in Tharuvaikulam, Vembar, Vaipar, Punnaikayal and Pazhayakayal. Sun drying method is the most commonly practised method in the entire study locality and fishes were sourced from the neighbouring landing centres. Fish drying yard primarily has coir mat and sand. Fishes having low value were generally used in the production process and the quantity purchased is influenced by the price of fish, quantity landed and season, similar to the studies on marketing of dry fish production around the world (Samad et al., 2009; Kolawole et al., 2010; Flowra et al., 2012). It was observed that during the course of fish drying, fishes were washed after descaling and internal organs were removed especially for highvalue species (not for small sized fish). Fishes were then kept immersed in salt water for one or two days depending on the type of fish, body water content, climate condition (relative humidity, air velocity and air temperature) and to some extent consumer preference. In general, one $\mathrm{kg}$ salt was used to produce $15 \mathrm{~kg}$ of dry fish $(1: 15)$, the

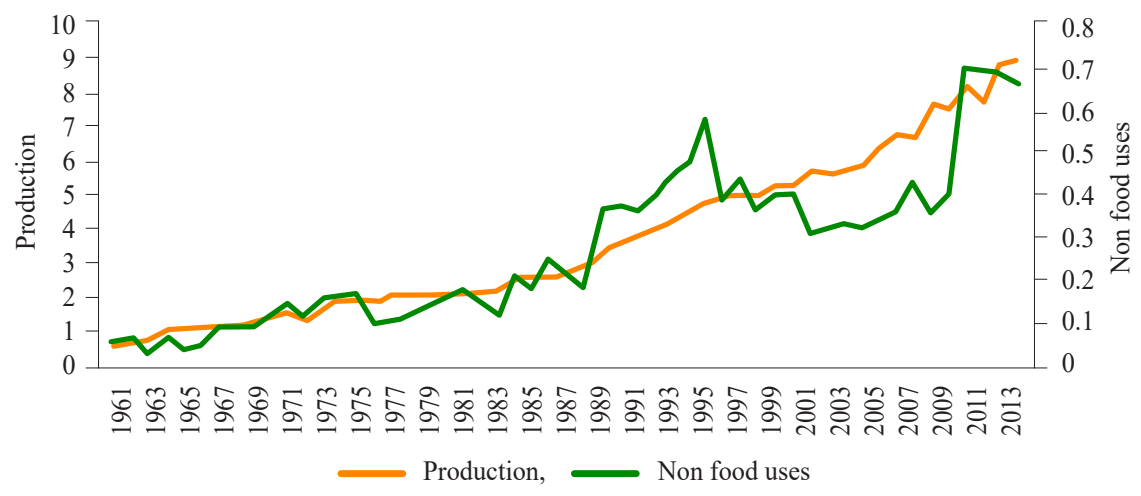

Fig. 1. Trend of non-food use of fish in India (1961-2013) 


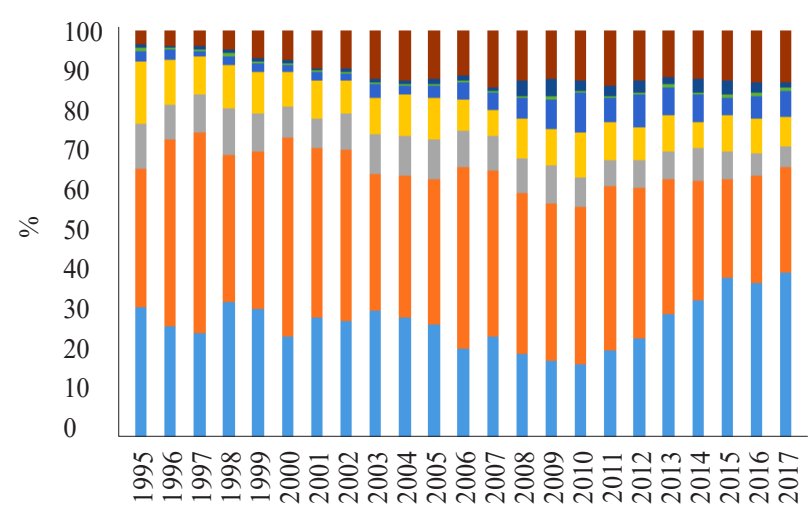

Frozen shrimp, $\square$ Frozen finfish, $\square$ Frozen cuttlefish, $\square$ Frozen squid,

- Dried items, a Live items, $\quad$ Chilled items, $\quad$ others

Fig. 2. Item-wise marine product exports from India (1995-2017)

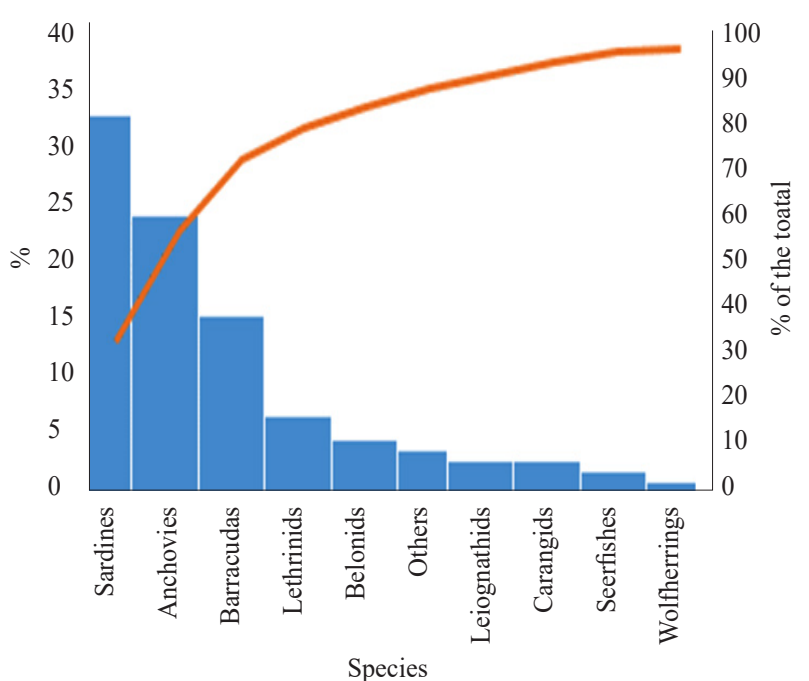

Fig. 3. Species composition of dry fish production in Thoothukudi

Table 1. Dispersion of total fish production in India (2013) (values in $1000 \mathrm{t}$ )

\begin{tabular}{|c|c|c|c|c|c|c|c|}
\hline Item & Production & $\begin{array}{l}\text { Import } \\
\text { quantity }\end{array}$ & $\begin{array}{l}\text { Domestic supply } \\
\text { quantity }\end{array}$ & $\begin{array}{l}\text { Export } \\
\text { quantity }\end{array}$ & Food & Feed & $\begin{array}{l}\text { Other } \\
\text { uses }\end{array}$ \\
\hline Fish body oil & 20 & 0 & 0 & 19 & 0 & 0 & \\
\hline Fish liver oil & 0 & 0 & 0 & 0 & 0 & & \\
\hline Freshwater Fish & 4367 & 7 & 4354 & 20 & 4354 & & \\
\hline Demersal Fish & 1012 & 0 & 784 & 228 & 375 & & \\
\hline Pelagic fish & 1114 & 21 & 948 & 187 & 676 & 272 & 409 \\
\hline Marine fish, other & 622 & 19 & 487 & 154 & 487 & & \\
\hline Crustaceans & 757 & 1 & 407 & 351 & 407 & & \\
\hline Cephalopods & 88 & 1 & 1 & 88 & 1 & & \\
\hline Molluscs, other & 18 & 0 & 10 & 8 & 10 & 0 & \\
\hline
\end{tabular}

Source: FAO stat

proportion being higher than other reports (Samad et al., 2009; Flowra et al., 2010). The penetrated salt helps to reduce the microbial activity and extends the self-life of dry fish.

\section{Species composition and price}

A total of nine varieties were predominantly used for dry fish production in Thoothukudi District. Results of the study revealed that sardine and anchovies accounted about $50 \%$ of the total dry fish production. Silver croaker, catfish, groupers, ribbonfish, lizardfish, mackerels and tuna were predominantly recorded in Veraval dry fish market, Gujarat (Bharda et al., 2017). The savalai hairtail, croakers, smeltwhitings, goatfish, threadfin breams, mackerel, warrior catfish, dorab wolf-herring and gold spot mullet were the commonly available dry fish in West Bengal (Payra et al., 2016; Bharda et al., 2017), which indicates that the species varied between location to location and season too. Fig.3 shows the individual species share (\%) to the total dry fish production in Thoothukudi District of India.
Dry fish price varied between market to market, types and size of the species. Seerfish fetched higher market price of ₹550 $\mathrm{kg}^{-1}$ followed by carangids ( $₹ 125 \mathrm{~kg}^{-1}$ ), belonids ( $₹ 115 \mathrm{~kg}^{-1}$ ), wolfherring (₹115 $\mathrm{kg}^{-1}$ ), barracudas (₹110 $\mathrm{kg}^{-1}$ ), lethrinids (₹105 $\mathrm{kg}^{-1}$ ), anchovies (₹95 kg-1), sardines (₹80 $\mathrm{kg}^{-1}$ ) and leiognathids (₹60 $\mathrm{kg}^{-1}$ ) (Fig. 4). Price fluctuation was noticed with higher price observed during the lean season than in peak season. The present study findings were coherent with the observations of Faruque et al. (2012).

\section{Cost, return and financial feasibility}

Average gross revenue of ₹5192 was earned in a week through dry fish sale. Total variable cost accounted for about $98 \%$ of the total cost, which was ₹2886 (Table 2). Of the total variable cost, the cost of fish accounted for $78.03 \%$, followed by transportation cost $14.52 \%$, market rent $3.04 \%$ and packaging cost $2.82 \%$. The total fixed cost was very meagre amount $(2 \%)$. Similar results were reported by Onyemauwa (2012) who studied fresh and dry fish marketing in south-east Nigeria, with net profit 


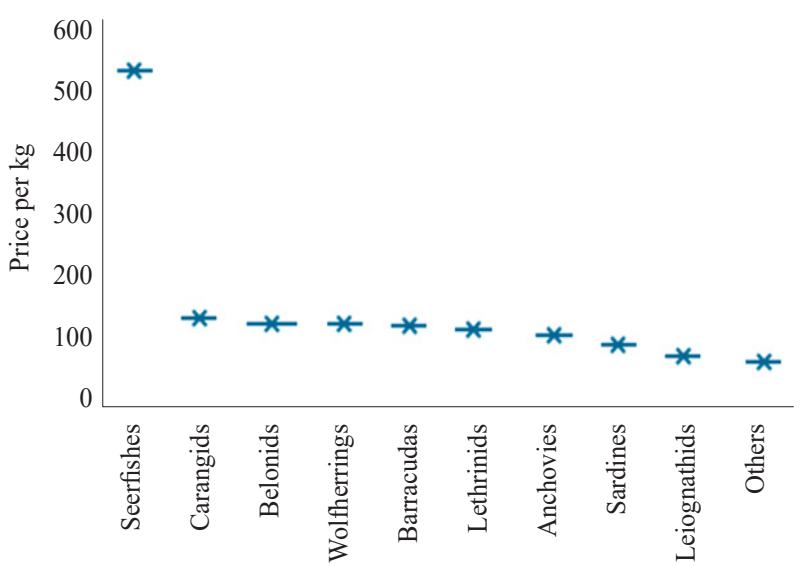

Fig. 4. Retail price of dry fish in Thoothukudi

Table 2. Economic performance of dry fish production

\begin{tabular}{lll}
\hline Criteria & Value (₹ per week) & $\%$ \\
\hline Gross revenue & 5192.10 & \\
\hline Variable cost & & \\
\hline Cost of fish & 2288.69 & 78.03 \\
Transportation cost & 426.04 & 14.52 \\
Packaging cost & 82.76 & 2.82 \\
Market rent & 89.31 & 3.04 \\
Total variable cost & 2886.79 & 98.42 \\
\hline Fixed cost & & \\
\hline Depreciation & 33.51 & 1.14 \\
Interest on loan payment & 12.97 & 0.44 \\
Total fixed cost & 46.48 & 1.58 \\
Total cost & 2933.27 & 100 \\
Net return & 2258.83 & \\
\hline
\end{tabular}

of ₹2258 per week. Economic performance, which is also referred as profit margin, is the ratio of net profit to gross revenue. In present study, the profit margin was found to be $43.48 \%$, which is considered as good.

Table 3 shows the financial feasibility of the dry fish producers in Thoothukudi District. The NPV was ₹3463 with IRR of $75 \%$ and BCR of 1.12 , which implies financial feasibility of dry fish production. A payback period of 1.654 years was recorded.

\section{Market margin and efficiency}

A high marketing efficiency and net marketing efficiency of 1.77 and 1.80 were noticed respectively

Table 3. Financial feasibility of dry fish production

\begin{tabular}{ll}
\hline Particulars & Values \\
\hline Net present value (₹) & 3463.64 \\
Simple rate of returns (\%) & 75 \\
Benefit cost ratio (\%) & 1.12 \\
Pay back period (years) & 1.64 \\
\hline
\end{tabular}

(Table 4), which indicated that the dry fish producers performed well. Onyemauwa (2012) reported lesser marketing efficiency in the dry fish production in southeast Nigeria. The marketing margin recorded was about $57 \%$ and this could be attributed to the higher selling price of dry fishes and good carcass recovery. Sugathapala et al. (2012) documented market margin of ₹50 per kg of fish. Kolawole et al. (2010) and Faruque et al. (2012) observed that a $\mathrm{kg}$ of fish was converted into $700 \mathrm{~g}$ recording good carcass recovery.

Table 4. Marketing efficiency measures

\begin{tabular}{ll}
\hline Criteria & Values \\
\hline Marketing efficiency & 1.77 \\
Net marketing efficiency & 1.80 \\
Marketing margin (\%) & 57.13 \\
Carcass recovery of fish ratio (\%) & $10: 7$ \\
\hline
\end{tabular}

\section{Marketing channel}

Marketing channels play a notable role in quality and price of the dry fish product. Dry fish reach the consumer through three marketing channels (Fig. 5) and the study revealed that about $60 \%$ of the dry fish reached the consumer through channel 1 and $23.3 \%$ through channel 2 and the remaining $16.7 \%$ through channel 3 . In channel 1 , producer directly sold the dry fish to consumer and selling takes place in streets. But in channel 2, the producer sold the dry fish to the retailer and marketing takes place in the local markets such as Eral, Thoothukudi and Udankudi. In channel 3, producer directly sold dry fish to the wholesaler and marketing takes place in other districts such as the Rajapalaym (Virudhunagar), Tirunelveli and Namakkal. Samad et al. (2009) and Flowra et al. (2010)

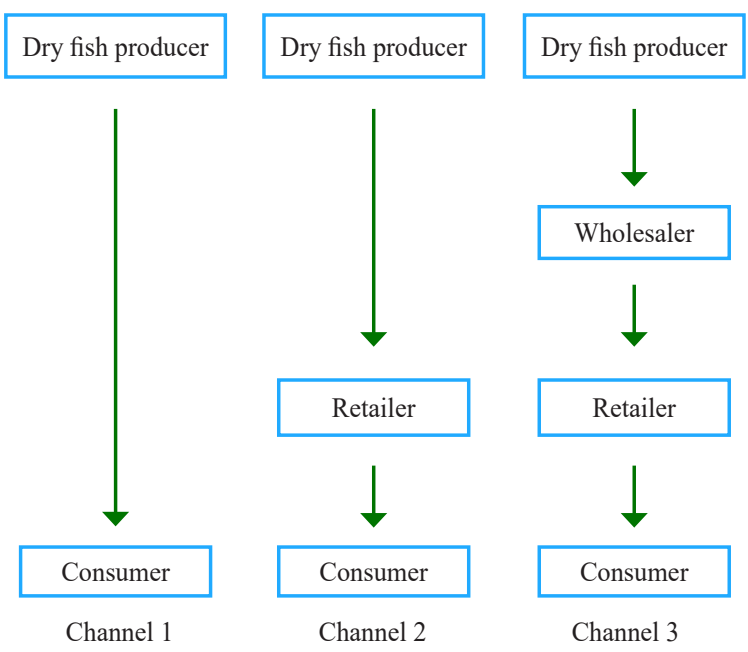

Fig. 5. Marketing channels of dry fish production in Thoothukudi District of India 
studied fish marketing channels and concluded that producer to consumer was the most efficient channel and had greater efficiency than that of the other marketing channels. They reported five marketing channels that included above-mentioned three marketing channels also. Marketing channels varied with nature of the product, location and type of market and further it confirmed with the observation of Faruque (2012).

\section{Regression approach}

A regression analysis was run to find out the variables, which significantly influenced the different variables of dry fish producer in Thoothukudi District of Tamil Nadu. The simple correlation coefficient of 0.998 margin, a 7.96 and 3123.22 unit increases respectively, in the income of producer is predicted in model 1 .

Drying is one of the most affordable post-harvest methods to preserve fish. Especially drying low value species extends the scope to avoid the fishes being spared for production of fishmeal. Dry fish production and trade offer a sustainable employment and income to the coastal fisherwomen. Our present study concluded that dry fish production was feasible financially as well as viable economically. It was observed that the dry fish production methods were not of the required sanitary standards. Improved fish drying methods successfully demonstrated by the fisheries research organisations should be promoted among the dry fish producers with adequate financial

Table 5. Factors influencing dry fish production in Thoothukudi District

\begin{tabular}{|c|c|c|c|c|c|c|c|c|c|}
\hline \multirow{2}{*}{ Particulars } & \multicolumn{3}{|c|}{ Model 1} & \multicolumn{3}{|c|}{ Model 2} & \multicolumn{3}{|c|}{ Model 3} \\
\hline & Coefficients & Standard Error & t Stat & Coefficients & Standard Error & t Stat & Coefficients & Standard Error & t Stat \\
\hline Cost of raw fish & 0.51 & 0.19 & 2.68 & $0.51 *$ & 0.15 & 3.40 & $0.54 *$ & 0.17 & 3.14 \\
\hline Transport charge & $3.19 *$ & 0.82 & 3.87 & $3.25 *$ & 0.81 & 4.02 & $3.26^{*}$ & 0.78 & 4.15 \\
\hline Packaging cost & $7.96^{*}$ & 1.70 & 4.68 & $7.49 *$ & 1.60 & 4.70 & 8.14 & 1.60 & 5.07 \\
\hline Market rent & -0.18 & 2.48 & -0.07 & -0.53 & 2.45 & -0.22 & -0.35 & 2.39 & -0.15 \\
\hline Marketing margin & $3123.22 *$ & 881.13 & 3.54 & $2895.53^{*}$ & 319.14 & 9.07 & $3244.40 *$ & 800.58 & 4.05 \\
\hline Market distance & 8.33 & 5.51 & 1.51 & 10.02 & 5.35 & 1.87 & 8.17 & 5.38 & 1.52 \\
\hline Age & 4.04 & 10.22 & 0.40 & & & & 5.03 & 9.65 & 0.52 \\
\hline Literacy & -229.37 & 154.51 & -1.48 & & & & -241.68 & 147.72 & -1.64 \\
\hline Experience & 12.19 & 33.06 & 0.37 & & & & & & \\
\hline Multiple R & $0.998^{\mathrm{a} \& \mathrm{~b}}$ & & & $0.998^{\mathrm{a} \& \mathrm{~b}}$ & & & $0.998^{\mathrm{c}}$ & & \\
\hline R square & 0.996 & & & 0.995 & & & 0.996 & & \\
\hline Adjusted R square & 0.944 & & & 0.951 & & & 0.947 & & \\
\hline Standard Error & 461.245 & & & 467.586 & & & 451.657 & & \\
\hline F value & 542.413 & & & 791.112 & & & 636.379 & & \\
\hline
\end{tabular}

Predictors: Cost of fish, Transportation charge, Packaging cost, Market levy, Market margin, Market distance, Age, Literacy and Experience aPredictors: Cost of fish, Transportation charge, Packaging cost, Market levy, Market margin, Market distance

${ }^{b}$ Predictors: Cost of fish, Transportation charge, Packaging cost, Market levy, Market margin, Market distance, Age and Literacy

"Variable significant at $\mathrm{p}<0.05$ level

was estimated in all the models, which indicates a high degree of correlation (Table 5). The $\mathrm{r}^{2}$ indicates the amount of total variation in the dependent variable, in this case, $99.6 \%$ can be explained in model 1 and 3 while $99.5 \%$ for model 2. The transportation, package and marketing margins significantly $(\mathrm{p}<0.05)$ influence income of the dry fish producer in model 1 . When we exclude the socioeconomic characteristics of the dry fish producer, cost of fish, transport charge, packaging cost and marketing margin significantly and positively influence income of the producers. The market rent negatively affected income of the producer in model 1, 2 and 3 and a unit of increased rent reduces the gross revenue by $-0.18,-0.53$ and -0.35 respectively. For every unit of increase in transportation cost, a 3.19 unit increase in producer income is predicted and similarly with respect to packaging cost and market support schemes, which would help to improve the livelihood of fishers as well as to ensure extended reach to potential markets in urban areas for maximisation of profit.

\section{Acknowledgements}

The authors gratefully acknowledge the Director, ICAR-CMFRI, Kochi, India for rending financial facilitates and support during the study period. Authors would like to thank Dr. I. Sivaraman, ICAR-CIFA, Bhubaneswar for his valuable comments to improve this manuscript.

\section{References}

Acharya, S. S. and Agarwal, N. L. 2004. Agricultural marketing in India, $4^{\text {th }}$ edn. Oxford and IBH Publishing, New Delhi. 
Balachandran, K. K. 2001. Post-harvest technology of fish and fish products. Daya Books, New Delhi, p. 77-104.

Bharda, S., Desai, A. Y., Kumar, T. R. and Kumar, T. J. 2017. Production of different type of dry fish and its yield measurement at Veraval, Gujarat, India. Res. J. Recent Sci., 6(7): 28-32.

CMFRI 2010. Marine fisheries censes 2010. Central Marine Fisheries Research Institute, Kochi.

CMFRI 2013. Annual Report 2012-13. Central Marine Fisheries Research Institute, Kochi.

Das, M., Rohit, P., Maheswarudu, G., Dash, B. and Ramana, P. V. 2013. Overview of dry fish landings and trade at Visakhapatnam Fishing Harbour. Mar. Fish. Infor. Ser. T\&E Ser., 215: 3-7.

Engle, C. R. 2010. Aquaculture economics and financing: management and analysis. John Wiley and Sons, NJ, USA.

FAO 2011. Global food losses and food waste - Extent, causes and prevention. Food and Agricultural Organisation, Rome, Italy, 4 pp.

Flowra, F. A., Sen, S. C., Galib, S. M., Kamal, M. M. and Islam, S. N. 2010. Dry fish marketing in Rajshahi and Thakurgaon. Bangladesh. Int. J. Bio. Res., 1(5): 13-16.

Flowra, F. A., Mohmud, M. S. and Mondal, R. C. 2012. Traditional fish drying and socio-economic status of dried fish processors of Chalanbeel area, Sirajganj, Bangladesh. Bangladesh J. Prog. Sci. Tech., 10(1): 65-68.

Faruque, M. O., Nazrul, K. S., Tonny, U. S., Islam, K. R., Dey, S. C., Mona, S. J. and Saha, D. 2012. Status of an ideal dry fish market of Bangladesh: A study on Asadganj dry fish market, Chittagong. Int. J. Life Sci. Biotech. Pharm. Res., 1(3): 214-225.

Immaculate, K., Sinduja, P., Velammal, A. and Patterson, J. 2013. Quality and shelf life status of salted and sun dried fishes of Tuticorin fishing villages in different seasons. Int. Food Res. J., 20(4): 1855-1859.

Kallon, A., Lebbie, A., Sturm, B., Garnett, T. and Wadsworth, R. 2017. Comparative studies of fish smoking and solar drying in the Sierra Leone artisanal fishing industry. J. Stored Prod. Postharvest Res., 8(3): 40-48. DOI: 10.5897/JSPPR2016.0217.

Kolawole, O. D., Williams, S. B. and Awujola, A. F. 2010. Indigenous fish processing and preservation practices amongst women in south-western Nigeria. Indian J. Trad. Knowl., 9(4): 668-672.

Kundu, R., Pradhan, A. and Bandyopadhyay, N. 2016. Nutritional and microbial quality of major sun-dried fishes from EGRA Government regulated dry fish market, West Bengal. J. Env. Soc., 13(1): 23-34.

Payra, P., Maity, R., Maity, S. and Mandal, B. 2016. Production and marketing of dry fish through the traditional practices in West Bengal coast: Problems and prospects. Int. J. Fish. Aquat., 4(6): 118-123.

Onyeauwa, C. S. 2012. Analysis of dry fish marketing in southeast Nigeria. J. Bio. Agri. Heal., 2(4): 74-84.

Radhakrishnan, K., Prakash, S., Narayanakumar, R., Krishnan, M., Madan, M. S. and Kumar, N. R. 2018. Economic analysis of marine fishing crafts in Thoothukudi province, Tamil Nadu. Indian J. Mar. Sci. 47(3): 653-659.

Samad, M. A., Galib, S. M. and Flowra, F. A. 2009. Fish drying in Chalan Beel areas, Bangladesh. J. Sci. Ind. Res., 44(4): 461-466. DOI: 10.3329/bjsir.v44i4.4599.

Sugathapala, R. M. N. S., Suntharabarathy, T. V. and Edirisinghe, U. 2012. Salt based dry fish processing and marketing by fishers of Minneriya Reservoir in Sri Lanka. Trop. Agric. Res., 23(4): 357-362. 